Research Article

\title{
A Study on The Awareness of Benefits, Perceptions of Borrowers to Problems in Finance, and Utilisation of Microfinance
}

Divya Sajan

PG Department of Commerce, Saintgits College of Applied Sciences, Pathamuttom P.O, Kottayam, India -686532

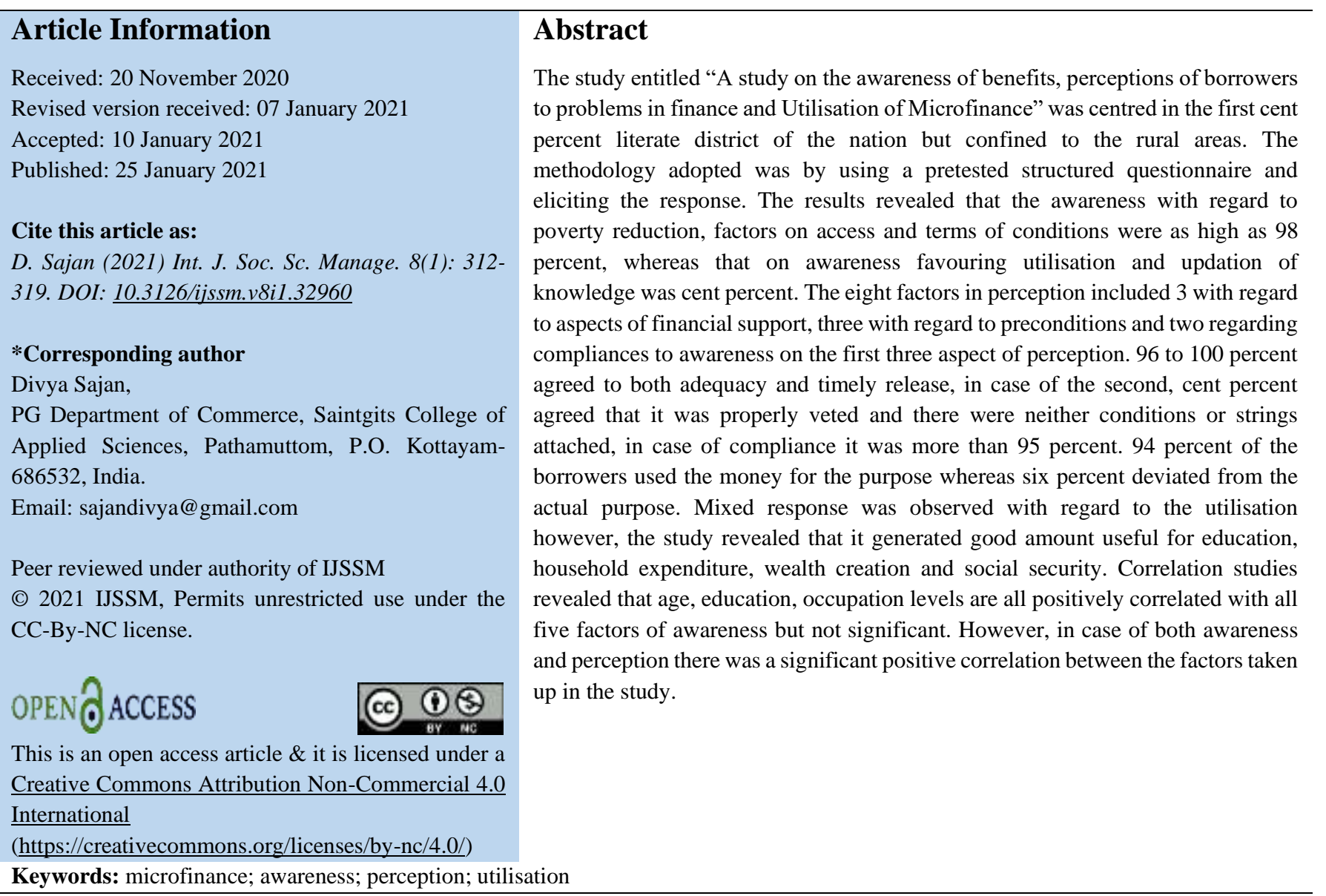

\section{Introduction}

Awareness and perception are closely linked. Awareness means knowledge or perception of a situation or facts and is meant and is used to spread knowledge of a particular problems or cause. A positive part of awareness is that it helps people to see clearly or have the ability to see things with more clarity and understanding. This in turn improves the critical skills, and aid in decision making.
Perception on the other hand is the ability to see hear or become aware of something through the senses in other words it can be depicted as a way in which something is regarded, understood or interpreted. Awareness when critically analysed and interpreted becomes perception. The importance of awareness and perception in the microfinance sector gains importance as the borrowers are underprivileged, less literate economically impoverished 
and lack any support whatsoever (Christen et al., 1995; Ledgerwood,1999; Robinson, 2001; Christen and Jayadeva, 2004; CGAP, 2013)

Again, microfinance is mostly sought by the rural poor who do not have access to credit and who cannot provide collateral security. Thus, the clientele in this sector has to be viewed as the economically impoverished who really are not just poor but also includes the poorest among the poor. Hence the potential of microfinance particularly in the developing and the underdeveloped parts of world is of great importance but is writ with many challenges. The vast majority of the Indian population also falls in this category who have no access to formal credit and hence either depend on rural moneylenders or on MFIs. In India the MFIs from its humble beginning by Ella Bhatt in 1974 has struck deep roots, has substantially grown and continues to grow. According to the NABARD annual report (2017-18) as on March, 2018. "The Self-Help Groups Bank linkage (SHGBLP) programme which started simply as a bank outreach programme, has through the passage of time slowly metamorphosed into a holistic programme for financial, economic, social and of late, technological capital building in rural areas. Thus, the SHG-Bank Linkage Programme has expanded at a fast pace in India to evolve into the largest microfinance programme in the world, and undoubtedly, it is the main microfinance programme in India. This success saga of the SHGBLP is made possible by the untiring efforts and the zeal of hundreds of channel partners, NGOs, Government, bank branches and above all millions of SHG women who reposed their trust in this initiative for ushering change in their own lives. As on 31st March 2018, there are 8.7 million SHGs out of which 5.02 million SHGs have outstanding bank loans of R75598 Cr to the Banks. The total deposits of SHGs with banks was to the tune of R19592 crore. There are more than 100 Scheduled Banks, 300 DCCBs, 27 State Rural livelihood Missions and over 5000 NGOs engaged in the Self-Help Group Bank Linkage Programme" (NABARD, 2017).

Utilisation of finance in the planned way will only reap success but if the capital money is misappropriated financial discipline is lost and business will take a U-turn. Microfinance is in small money terms and bound as a scarce resource for a specific purpose. Often this seed money just suffices the requirements and hence if misappropriated will end up with deleterious consequences thus only an efficient monitoring and evaluation will give the much-needed impetus required for the success.

Hence this study was taken up with broad objective of

1)studying the awareness of the borrowers with regard to the credit

2) studying the perception level of the borrowers and

3) studying the actual utilisation of Microfinance

\section{Review of Literature}

Research on awareness and perception of borrowers/ clients in microfinance are limited. The available few revolve around the broad concept of" financial literacy". A systematic review of the evidence of microfinance impact conducted in 2012 came up almost empty handed. 14,000 citations were assessed against inclusion criteria and reduced to 84 relevant studies. Of these, 17 were judged to be of good enough quality for inclusion in the review (Dominic, 2015). This highlights the shallowness in the actual depth of the studies available in this broad realm.

One of the big obstacles in research on financial literacy is that the studies are based on success stories, mostly measured on relative returns obtained. Measuring financial literacy itself is a complex task but awareness and perception is no doubt an underlying plank on which the indices are built.

Rutledge et al. (2008) are of the opinion that awareness a key component in financial literacy gives a client a knowledge, skills and confidence to understand and evaluate the information they received empower them to purchase financial products and services that meet their needs. On the other hand, Tiwari et al. (2008) are of the learned opinion that awareness of financial literacy in microfinance is one among the research aspects that has not been investigated at length. The unified code of conduct developed by MFIN and sadhan emphasise that issue of client education and clearly specifies that MFIs must have an educated person to raise client awareness of the options, choices and responsibilities vis- a -vis financial products and services. Further it was emphasized that regular check on client awareness and understanding has to be ensured. Research carried out in Sub-Sahara Africa inferred that there is improved access to microfinance by women (Gordan et al., 2011) The study on awareness level of borrowers done in Nagpur by Sharma and Deshmukh (2013) done in Nagpur revealed that the awareness level about microfinance of the sample studied is $90.6 \%$. So also, the awareness level of the urban poor people about various schemes and concept of microfinance was found to be very high. Another study taken up in Varanasi by Kalra et al. (2015) confirmed that low levels of money management knowledge as a major limitation in Microfinance and developed a microfinance client awareness index which takes values between 1 and 2 . 1 indicating complete ignorance and 2 indicating complete financial awareness. Contrary to this, the work of Pathak (2017) revealed that 81 per cent of the study group were fully aware of the various microfinance schemes.

A critical scrutiny of the entire work done on perception analysis is skewed towards the success or failure of the MFIs Two major works in this direction are the works of Kamal and Jalaleddine (2015), who after review of the 
existing literature on the impact of microfinance broadly divided into three categories a) The first category examines the impact of microfinance on poverty (Hulme and Mosley, 1996; Copestake \& James, 2002; Khandker, 2005; Tedeschi, 2010). b) The second strand of literature deals with the impact of microfinance on women's empowerment (Hashemi et al., 1996; Rahman et al., 2009; Garikpati, 2012). The third series of studies highlight other effects of microfinance such as the impact on education, health, nutrition, consumption level and build assets (Deloach et al. 2011; Lammana et al., 2011; Gertler et al., 2006; Jacobsen, 2009; Kouassi, 2008; Leatherman \& Dunford, 2010; Hazarika and Sarangi, 2008).

Dominic (2015) critically analysed all papers, proceedings and work done so far and came to the conclusion that perception is based on direction of movement to success or failure of MFI.

Siddique and Gilal (2012) ascertained the perception and realities of Microfinance in Pakistan. The results show that there is surprising clash do exist in urban and rural people's mind share: what they perceived is amazingly opposite to reality. Rural people have perception that they are taking loan more as compare to urban people but in reality, it's erroneous. On the other hands urban people have perception that they are not taking loan as compared to rural people but in reality, urban people are taking much more loan than rural people. There is also vast perception gap existing in urban and rural people about microfinance loan usage.

Meiyappan and Annamalai (2013) reported based on a study of the perception of the borrowers of Non-Banking Finance Company (NBFC) Microfinance Finance Institutions (MFIs) in Kanchipuram district in Tamil Nadu state in India on their self-confidence observed significant changes were observed over their socio-economic factors. The perception of Hermes (2014) is that microfinance reduces inequalities. Kalra et al. (2015) reported the low levels of money management knowledge deter clients and potential clients of microfinance understanding and utilising the range of products and services available.

Dominic (2015) based on studies from late 2010 almost the time when the bad news about microfinance hit the press reported that while most of the European and American participants in Credit Suisse's microfinance survey stated early 2011 that the criticism of microfinance had not changed their perception, they had reacted by becoming more careful in selecting the organizations and institutions they supported. The wealth holders cited the general media as their primary source of information in guiding decisions about microfinance investments and donations. Some admitted that this heavy reliance on the media could be a risk for the industry. Several participants had the impression that the debate and dialogue after the Andhra Pradesh situation in India was not proactively managed by the microfinance industry, rather it was left in the hands of newspaper columnists and bloggers.

Another reason for underutilisation or misutilisation is the lack of sound supervisory mechanism as that happened in the case of the Ireland Irish loan funds (Hollis and Sweetman, 2001) or a control group as in fisheries sector of India (Gopal et al. ,2012)

Still later, Lewinski et al. (2018) using global data set of MFIs in 77 countries inferred that provision of non-financial services do not harm or improve MFIs financial sustainability and efficiency. The results however suggest that the provision of social service is associated with improved loan quality and greater depth of outreach.

Utilisation is the planned and programmed use of allotted funds following strict financial discipline that is of utmost importance.

Siddique and Gilal (2012) in their studies based in Pakistan inferred that Urban people get loan for pure intention to invest in business activities and personal use whereas rural people get loan for the purpose of using in agricultural activities and most importantly rural people never take microfinance loan for personal use. The thinking style of females is extremely contrary to males in terms of "in what ways microfinance helps them".

In more recent time researchers have come to the conclusion that microcredit is not for every household and it does not lead to miraculous social transformation. Its principal impact seems to allow some households to reduce spending on temptation goods or leisure to finance lumpy (large) purchases, either for their home or in order to establish or expand a business. (Banerjee et al.,2013).

\section{Research Methodology}

The study was undertaken using a structured questionnaire schedule developed for the purpose in consultation with experts in the field. This was pre-tested by an expert team of Senior officers working in microfinance with whose expertise the questionnaire schedule was finalised.

The study was centred in Kottayam district as it is a cent percent literate district Based on the inputs from the regulatory body. leading microfinance company in the district was identified. Five clusters were randomly selected which formed the first strata. From these hundred borrowers were randomly selected. from the rural parts of the district initially but then restricted to fifty as many of them did not completely fill the questionnaire. Organisers of the Microfinance institution helped in identifying the cluster and the borrowers were selected by random pick.

The structure questionnaire schedule was given to the borrower directly and the response to each aspect was obtained. The doubts and queries of the borrower were 
immediately clarified on the spot so that the data could be collected without any bias.

The broad personal details of the borrower were collected from the schedule and were further categorised into different groups with each group being assigned a particular score. The data on awareness and perception were calculated on a percentage basis

The mean values of improvement in physical assets, month income and employment generation in the pre-credit and post-credit scenario was analysed using paired "t test" (Snedecor and Cochran, 1967). The correlations on financial parameters, were worked out with the personal profile or characters of the borrower using Spearmans correlation coefficient or kendalls correlation coefficient utilising SPSS Package version 16.0.

\section{Results and Discussions}

The results of the study are presented under the broad subheadings as given below:

\section{Awareness of Benefits of Microfinance}

The awareness of the benefits of microfinance was rated on five-point scale. The data are presented in Table 1.

In all, five aspects were taken to study the awareness of the borrowers. A Critical scrutiny of the data reveal that the borrowers were well aware of the benefits of microfinance. The favourable response was reflected in all the five aspects in the study in which almost the range of agreement varied from ninety eight percent to cent per cent. Only two percent disagreed on its positive aspect of poverty reduction and easy accessibility.

Another major aspect of the study was the association of major personal characters of the borrower with awareness aspects which is presented as Table 2 .
The correlation of characters revealed that there is negative correlation between age and education which is also significant. Age, education, occupation and income levels are all positively correlated with all the five awareness characters under study but not significant. The most important aspect is that all the five awareness characters are high positively correlated between themselves and is also significant at one percent level implying the equal importance of all the five selected characters.

\section{Perception of The Borrowers to Problems in Microfinanace}

The data on the perception of the borrowers to financial aspects is given in Table 3 .

A close look on the various financial aspects reveals that the borrowers are more or less happy about the situation. In all the eight aspects the range of positive perception ranged from 88 to 100 per cent. Four per cent of the borrowers felt that there is lack of adequate financial support meaning that the credit size or microloan size can be increased. All the borrowers agreed that there was timely support, no delay in release, no pre conditions to be satisfied and no paraphernalia involved. However, eight per cent of the borrowers are of the considered view that there is no proper vetting or actual assessment of the project. Four per cent also stressed on creating awareness of repayment.

The correlation between various aspects of the borrower and the major financial parameters involved in microfinance presented in Table 4 gave no definite trend except that the correlation coefficient between the various financial parameters taken in the study were positive and statistically significant even at one percent level revealing that the parameters were of maximum significance.

Table 1: Data showing the awareness on the different benefits of microfinance

\begin{tabular}{|l|l|l|l|l|l|l|}
\hline S.N. & \multicolumn{1}{|c|}{ Aspect } & $\begin{array}{l}\text { Strongly } \\
\text { disagree }\end{array}$ & Disagree & $\begin{array}{l}\text { Neither agree } \\
\text { or disagree }\end{array}$ & Agree & $\begin{array}{l}\text { Strongly } \\
\text { agree }\end{array}$ \\
\hline 1 & Poverty reduction & 2 & 0 & 0 & 32 & 66 \\
\hline 2 & Easy accessibility & 2 & 0 & 0 & 32 & 66 \\
\hline 3 & Favouring prompt utilization & 0 & 0 & 0 & 36 & 64 \\
\hline 4 & Favouring updating of knowledge & 0 & 0 & 0 & 36 & 64 \\
\hline 5 & Easy terms and conditions & 0 & 0 & 0 & 32 & 68 \\
\hline
\end{tabular}

Table 3: Perception of the borrowers to financial aspect on a percentage basis

\begin{tabular}{|l|l|l|l|l|l|l|}
\hline S.N. & Aspect & $\begin{array}{l}\text { Strongly } \\
\text { disagree }\end{array}$ & disagree & $\begin{array}{l}\text { Neither } \\
\text { disagree or } \\
\text { agree }\end{array}$ & Agree & $\begin{array}{l}\text { Strongly } \\
\text { agree }\end{array}$ \\
\hline 1 & Lack of adequate financial support & 96 & 0 & 0 & 2 & 2 \\
\hline 2 & Lack of timely support & 100 & 0 & 0 & 0 & 0 \\
\hline 3 & Delay in timely release & 100 & 0 & 0 & 0 & 0 \\
\hline 4 & Many pre conditions to be satisfied & 100 & 0 & 0 & 0 & 0 \\
\hline 5 & Too many strings attached & 100 & 0 & 0 & 0 & 0 \\
\hline 6 & There is proper vetting & 8 & 0 & 0 & 4 & 88 \\
\hline 7 & An assurance on compliance of use & 2 & 0 & 0 & 0 & 98 \\
\hline 8 & Creating Awareness of repayment & 4 & 0 & 0 & 0 & 96 \\
\hline
\end{tabular}


Table 2: Correlation between personal character of borrower and awareness aspects of the microfinance

\begin{tabular}{|c|c|c|c|c|c|c|c|c|c|c|c|}
\hline & & & Age & Edu & Occu & Incom & Awaa & Awab & Awac & Awad & Awae \\
\hline \multirow[t]{27}{*}{ Kendall's tau_b } & Age & Corr. Coeff. & 1 & & & & & & & & \\
\hline & & Sig. (2-tail) & . & & & & & & & & \\
\hline & & $\mathrm{N}$ & 50 & & & & & & & & \\
\hline & Edu & Corr. Coeff. & $.329(* *)$ & 1 & & & & & & & \\
\hline & & Sig. (2-tail) & 0.009 & . & & & & & & & \\
\hline & & $\mathrm{N}$ & 50 & 50 & & & & & & & \\
\hline & Occu & Corr. Coeff. & -0.1 & 0.141 & 1 & & & & & & \\
\hline & & Sig. (2-tail) & 0.444 & 0.302 & . & & & & & & \\
\hline & & $\mathrm{N}$ & 50 & 50 & 50 & & & & & & \\
\hline & Incom & Corr. Coeff & 0.167 & 0.009 & 0.092 & 1 & & & & & \\
\hline & & Sig. (2-tail) & 0.198 & 0.95 & 0.514 & . & & & & & \\
\hline & & $\mathrm{N}$ & 50 & 50 & 50 & 50 & & & & & \\
\hline & Awaa & Corr. Coeff. & 0.071 & -0.008 & 0.101 & 0.113 & 1 & & & & \\
\hline & & Sig. (2-tail) & 0.585 & 0.952 & 0.475 & 0.421 & . & & & & \\
\hline & & $\mathrm{N}$ & 50 & 50 & 50 & 50 & 50 & & & & \\
\hline & Awab & Corr. Coeff. & 0.071 & -0.008 & 0.101 & 0.199 & $.915(* *)$ & 1 & & & \\
\hline & & Sig. (2-tail) & 0.585 & 0.952 & 0.475 & 0.156 & 0 & . & & & \\
\hline & & $\mathrm{N}$ & 50 & 50 & 50 & 50 & 50 & 50 & & & \\
\hline & Awac & Corr. Coeff. & 0.153 & 0.036 & 0.107 & 0.221 & $.774(* *)$ & $.774(* *)$ & 1 & & \\
\hline & & Sig. (2-tail) & 0.242 & 0.791 & 0.453 & 0.119 & 0 & 0 & . & & \\
\hline & & $\mathrm{N}$ & 50 & 50 & 50 & 50 & 50 & 50 & 50 & & \\
\hline & Awad & Corr. Coeff. & 0.169 & -0.168 & 0.107 & 0.221 & $.604(* *)$ & $.689(* *)$ & $.826(* *)$ & 1 & \\
\hline & & Sig. (2-tail) & 0.198 & 0.219 & 0.453 & 0.119 & 0 & 0 & 0 & . & \\
\hline & & $\mathrm{N}$ & 50 & 50 & 50 & 50 & 50 & 50 & 50 & 50 & \\
\hline & Awae & Corr. Coeff. & 0.1 & -0.088 & 0.098 & 0.081 & $.507(* *)$ & $.507(* *)$ & $.736\left(^{* *}\right)$ & $.825(* *)$ & 1 \\
\hline & & Sig. (2-tail) & 0.444 & 0.519 & 0.493 & 0.566 & 0 & 0 & 0 & 0 & . \\
\hline & & $\mathrm{N}$ & 50 & 50 & 50 & 50 & 50 & 50 & 50 & 50 & 50 \\
\hline
\end{tabular}


Table 4: Correlation between various aspects of the borrower and the major financial parameters

\begin{tabular}{|c|c|c|c|c|c|c|c|c|c|c|c|c|c|}
\hline & & Age & Edu & Occu & Incom & Fin1 & Fin2 & Fin3 & Fin4 & Fin5 & Fin6 & Fin7 & Fin8 \\
\hline \multirow[t]{3}{*}{ Age } & Correlation Coeff & 1 & & & & & & & & & & & \\
\hline & Sig. (2-tailed) & . & & & & & & & & & & & \\
\hline & $\mathrm{N}$ & 50 & & & & & & & & & & & \\
\hline \multirow[t]{3}{*}{ Edu } & Correlation Coeff & $-.329(* *)$ & 1 & & & & & & & & & & \\
\hline & Sig. (2-tailed) & 0.009 & . & & & & & & & & & & \\
\hline & $\mathrm{N}$ & 50 & 50 & & & & & & & & & & \\
\hline \multirow[t]{3}{*}{ Occu } & Correlation Coeff & -0.1 & 0.141 & 1 & & & & & & & & & \\
\hline & Sig. (2-tailed) & 0.444 & 0.302 & . & & & & & & & & & \\
\hline & $\mathrm{N}$ & 50 & 50 & 50 & & & & & & & & & \\
\hline \multirow[t]{3}{*}{ Incom } & Correlation Coeff & 0.167 & -0.009 & -0.092 & 1 & & & & & & & & \\
\hline & Sig. (2-tailed) & 0.198 & 0.95 & 0.514 & . & & & & & & & & \\
\hline & $N$ & 50 & 50 & 50 & 50 & & & & & & & & \\
\hline \multirow[t]{3}{*}{ Fin1 } & Correlation Coeff & -0.19 & 0.1 & -0.029 & -0.131 & 1 & & & & & & & \\
\hline & Sig. (2-tailed) & 0.145 & 0.461 & 0.838 & 0.352 & . & & & & & & & \\
\hline & $\mathrm{N}$ & 50 & 50 & 50 & 50 & 50 & 50 & & & & & & \\
\hline \multirow[t]{3}{*}{ Fin2 } & Correlation Coeff & . & . & . & . & . & . & . & . & . & . & . & . \\
\hline & Sig. (2-tailed) & . & . & . & . & . & . & . & . & . & . & . & . \\
\hline & $\mathrm{N}$ & 50 & 50 & 50 & 50 & 50 & 50 & 50 & & & & & \\
\hline \multirow[t]{3}{*}{ Fin3 } & Correlation Coeff & . & . & . & . & . & . & . & . & . & . & . & . \\
\hline & Sig. (2-tailed) & . & . & . & . & . & . & . & . & . & . & . & . \\
\hline & $\mathrm{N}$ & 50 & 50 & 50 & 50 & 50 & 50 & 50 & & & & & \\
\hline \multirow[t]{3}{*}{ Fin4 } & Correlation Coeff & . & . & . & . & . & . & . & . & . & . & . & . \\
\hline & Sig. (2-tailed) & . & . & . & . & . & . & . & . & . & . & . & . \\
\hline & $\mathrm{N}$ & 50 & 50 & 50 & 50 & 50 & 50 & 50 & 50 & & & & \\
\hline \multirow[t]{3}{*}{ Fin5 } & Correlation Coeff & . & . & . & . & . & . & . & . & . & . & . & . \\
\hline & Sig. (2-tailed) & . & . & . & . & . & . & . & . & . & . & . & . \\
\hline & $\mathrm{N}$ & 50 & 50 & 50 & 50 & 50 & 50 & 50 & 50 & 50 & & & \\
\hline \multirow[t]{3}{*}{ Fin6 } & Correlation Coeff & -0.156 & -0.014 & 0.052 & -0.016 & -0.24 & . & . & . & . & 1 & & \\
\hline & Sig. (2-tailed) & 0.227 & 0.915 & 0.712 & 0.911 & 0.087 & . & . & . & . & . & & \\
\hline & $\mathrm{N}$ & 50 & 50 & 50 & 50 & 50 & 50 & 50 & 50 & 50 & 50 & & \\
\hline \multirow[t]{3}{*}{ Fin7 } & Correlation Coeff & -0.139 & 0.096 & 0.02 & 0.092 & 0.029 & . & . & . & . & $.398(* *)$ & 1 & \\
\hline & Sig. (2-tailed) & 0.29 & 0.483 & 0.886 & 0.514 & 0.838 & . & . & . & . & 0.005 & . & \\
\hline & $\mathrm{N}$ & 50 & 50 & 50 & 50 & 50 & 50 & 50 & 50 & 50 & 50 & 50 & \\
\hline \multirow[t]{3}{*}{ Fin8 } & Correlation Coeffi & -0.085 & -0.097 & 0.029 & 0.132 & 0.041 & . & . & . & . & $.532\left({ }^{* *}\right)$ & $.700(* *)$ & 1 \\
\hline & Sig. (2-tailed) & 0.515 & 0.479 & 0.838 & 0.351 & 0.771 & . & . & . & . & 0 & 0 & . \\
\hline & $\mathrm{N}$ & 50 & 50 & 50 & 50 & 50 & 50 & 50 & 50 & 50 & 50 & 50 & 50 \\
\hline
\end{tabular}


Table 5: Utilisation of microfinance generated income for different purposes

\begin{tabular}{|l|l|l|l|l|}
\hline & Useful & Not useful & Percent useful & Percent not useful \\
\hline Asset building & 32 & 18 & 64 & 36 \\
\hline Initiating own business \& development & 43 & 7 & 86 & 14 \\
\hline House hold expenditure & 29 & 21 & 58 & 42 \\
\hline Education of children & 36 & 14 & 72 & 28 \\
\hline Wealth creation purpose & 44 & 6 & 88 & 12 \\
\hline Acquiring land & 4 & 46 & 8 & 92 \\
\hline Meeting medical expense & 9 & 41 & 18 & 82 \\
\hline Emergencies & 14 & 36 & 28 & 72 \\
\hline Social security & 43 & 7 & 86 & 14 \\
\hline Farm mechanisation & 0 & 50 & 0 & 100 \\
\hline
\end{tabular}

\section{Utilization of Microfinance Generated and Related Income for Different Purposes}

The utilisation of microfinance generated income for various purposes is given in Table 5. Analysis of the data revealed that the income was useful for different purposes. Sixty four percent of the borrowers rated it as useful for asset building, eighty six percent for initiating and developing one's own business, fifty eight percent utilised it for household expenses, seventy two percent opined that it was useful for education of children, eighty-eight utilised the same for wealth creation purpose but only for eight percent it was useful for acquiring land. So also, it was useful only for eighteen percent for meeting medical expenses and twenty eight percent for emergency situations. It was not useful for anyone in promoting farm mechanisation but to the vast majority of eighty-eight per cent it meant Social security.

The results are actually a manifestation of the high educational background of the borrowers as most of them have completed their plus two level and have a fair grasp of the banking rules and regulations. Another aspect that favoured their levels of awareness and perception was that they were already borrowers and some of them had repaid the credit drawn and started a new microfinance policy.

\section{Acknowledgement}

The author gratefully acknowledges the financial support received in the form of scholarship and the MFI for permitting to take up the study.

\section{References}

Banerjee A, Dufflo E, Glenester E and Kinnan G (2013) The miracle of microfinance? Evidence from randomised evaluation, Massachussetes Institute of Technology, Working paper 13-09.

CGAP (2013) What is microfinance (online). Available at http://www.cgap.org/about/faq/what-microfinance

Christen RP and Jeyadeva (2004) Financial institutions with a double bottom line: Implications for the future of microfinanace.
Christen RP, Rhyne E, Vogel R and McLean C (1995) Maximising the outreach of microenterprise finance: AN analysis of successful microfinance programms.USAID Programms and operations assessment report No.10, Washington DC: US agency for international development.

Copestake J, Dawson P, Fanning JP, Mackay A and Wright RK (2005) Monitoring the diversityof the poverty outreach and impact of microfinance: a comparison of methods using data from Peru. Development policy review 23(6): 703-723.

Deloach SB and Lamanna E (2011) Measuring the impact of Microfinanace on child health outcomes in Indonesia. World Development 39: 1808-1819.

Dominic S (2015) The perception of microfinance -Impact by selected stake holders. CAS Internationale Zusammenareit, Fuhren uber Grenzen http://www.researchgate.net/publication/290084305

Garikipati S (2008) The impact of lending of lending to women on household vulnerability and womens empowerment: Evidence from India, World Development 36: 2620-2642.

Gertler P, Levine D and Moretti E (2006) Do microfinanace programmes help families insure consumption against illness? Centre for International and development economics research, Working paper series: 1045.

Gopal N, Jayanthi P, Chandrasekhar V and Meenaumari V (2012) A study on the availability and utilisation of microcredit in the traditional fisheries sector of Kerala, India. Gender in aquaculture and Fisheries: Moving the agenda forward. Asian Fisheries Science special 255: 243-250.

Gordon AN (2011) Improving maternal health care utilisation in sub-Saharan Africa. International journal of health quality assurance 24(8): 601-610.

Hashemi S, Schuler SR and Riley A (1996) Rural credit programms and women's empowerment in Bangladesh. World Development 24: 635-653.

Hazarika G and Sarangi S (2008) Household access to microcredit and childwork in rural Malawi. World Development 36: 843

Hermes N (2014) Does microfinanace affect inequality. Applied Economics 46(9): 1021-1034. 
Hollis A and Sweetman A (2001) The life-cycle of a microfinance institution: the Irish loan funds. Journal of Economic Behaviour \& Organisation 46(2001): 291-311.

Hulme D and Mosley P (1996) Finance against poverty. Rutledge Publications, London.

Kalra V, Mathur HP and Rajeev PV (2015) Microfinance clients' awareness index: A measure of awareness and skills of microfinance clients IIM Management Reviews 27: 252266.

Kamal BHM and Jeleleddine BR (2015) Microfinance and Poverty reduction: A review and synthesis of empirical evidence. Procedia-Social and Behavioural Sciences 195: 705-712.

Khandker SR (2012) Grameen bank lending: Does group liability matter? The World Bank, Policy Research working paper series:6204

Kouassi MJ (2008) Microfinanace and Health: Ph D thesis Haward University

Leatherman S, Metcalfe M, Geissler K and Dufford C (2012) Integrating microfinance and health strategies: Examining the evidence to inform policy and practice. Health policy and Planning 27: 85-101.

Ledgerwood J (1999). Microfinance hand book: An institutional and financial perspectives, sustainable banking with the poor., Washington, DC, World Bank.

Lensink R, Mersland R, Hong VNT and Zamore S (2018) Microfinance institutions benefit from integrating financial and non-financial services. $J$ applied Econ 50(21): 2386-2401.

Meiyappan MS and Annamalai S (2013) Impact of microfinanace on self-confidence of NBFC-MFI borrowers in Kanchipuram district of Tamil Nadu, International Journal of Advanced research in Management and Social science 2(5): 198-206.
NABARD (2017-18), Annual Report for the year 2017-18. Mumbai

Pathak (2017) A study of microfinanace schemes and its awareness in Madhya Pradesh. International Journal in Business management 5(8): 1-8.

Robinson M (2001) The microfinance revolution: Sustainable finance for the poor. The World Bank.

Rutledge SL, Annamalai N, Lester R and Symonds RL (2008) Good practices for consumer protection and financial literacy in Europe and central Asia: a diagnostic tool. ECSPF Working Paper 001, The World Bank. $<$ http://siteresources.worldbank.org/INTECAREGTOPP RVSECDEV/Resources/GoodPractices_August2010.pdf

Sharma SA and Deshmukh A (2013) A study of microfinance facilities and analysing the awareness levels of people about microfinance in Nagpur city. International Journal of Social science and interdisciplinary research 2(3): 116131.

Siddique and Gilal (2012) Perception towards microfinanace in Pakistan. Asian Journal of Business and management 1(10): 6-10

Snedecor GW and Cochran WG (1967) Statistical methods (1st Ed.) Oxford and IBH publications New Delhi

Takeshi I and Hamori S (2013) Financial permeation as a role of microfinance: has microfinance really been a viable financial intermediary for helping the poor? Applied financial economics 1567-1578

Tiwari R, Khandelwel A and Ramji M (2008) How do microfinance clients understand their loans? Institute for Financial Management and Research, Centre for Micro Finance Working Paper Series, 25. 